特集記事 ワークショップ報告

ワイルドはセクシーだ!

内藤 健 ${ }^{1,2}$ ・ 高橋 有 ${ }^{1,3)} \cdot$ 山内卓樹 3,4$)$ ・福島健児 $\left.3,5,6\right)$ 風間裕介 ${ }^{7)}$ ・ 江崎文一 8) ・ 友岡憲彦 1$)$

1) 農業生物資源研究所, 茨城県つくば市, 干 305-8602

2) 科学技術振興機構, さきがけ, 埼玉県川口市，７332-0012

3) 日本学術振興会, 特別研究員

4) 名古屋大学大学院生命農学研究科, 愛知県名古屋市, $=464-8601$

5) 基礎生物学研究所, 愛知県岡崎市, $\bar{T} 444-8585$

6) 総合研究大学院大学生命科学研究科基礎生物学専攻, 愛知県岡崎市, ₹ 444-8585

7) 理化学研究所, 仁科加速器研究センター, 埼玉県和光市, † 351-0198

8) 岡山大学資源植物科学研究所, 岡山県倉敷市, 干 710-0046

\title{
Wild is sexy!
}

Ken Naito ${ }^{1,2)}$, Yu Takahashi ${ }^{1,3)}$, Takaki Yamauchi ${ }^{3,4)}$, Kenji Fukushima $^{3,5,6)}$, Yusuke Kazama ${ }^{7)}$, Bunichi Ezaki ${ }^{8)}$ and Norihiko Tomooka ${ }^{1)}$

1) National Institute of Agrobiological Sciences, Tsukuba, Ibaraki 305-8602

2) Japan Science and Technology Agency, PRESTO, Kawaguchi, Saitama 332-0012

3) Research Fellow of the Japan Society for the Promotion of Science

4) Graduate School of Bioagricultural Sciences, Nagoya University, Nagoya, Aichi 464-8601

5) National Institute for Basic Biology, Okazaki, Aichi 444-8585

6) Department of Basic Biology, School of Life Science, Graduate University of Applied Studies, Okazaki, Aichi 444-8585

7) RIKEN Nishina Center, Wako, Saitama 351-0198

${ }^{8)}$ Institute of Plant Science and Resources, Okayama University, Kurashiki, Okayama 710-0046

キーワード

食虫植物, 性染色体, エピジェネティックス, Neo-domestication

\section{緒 言}

ワイルドはセクシーである。野生植物にはモデル植物 と一線を画した魅力が秘められているといらことだ。確 かに，シロイヌナズナやイネの全兮ム解読は植物科学 の一つの金字塔となった。これによって，より多くの研 究者がこれらのモデル植物を扱らようになり，実験系が 整備され，さらに多くの研究者が集まった。 その結果， 植物の分子生物学・分子遺伝学は飛躍的に発展した。一 方で，モデル植物の登場が，研究の画一化を誘導してし まったことも事実である。野生植物がいかに魅力的な特 徵を備えていようとも，敢光てそれらに挑もらとする研 究者が増えることはなかった。研究対象としての扱いゃ すさはモデル植物に敵わなかったのがその最大の理由で あろら。しかしながら, 次世代シーケンサーの登場によっ て，そのようなモデル植物の圧倒的優位は崩れつつある。 ゲノムが解読されていないなら自分で読んでしまえばよ

2015 年 2 月 9 日受領

Correspondence: takahashi0126@affrc.go.jp
い，そんな時代が開かれつつあるのだ。そうであればこ そ, 環境適応, 性決定, 形態発生なぞ, 野生種がもつ魅 力的な特性の数々が顧みられるべきである. 全世界で収 集・保存されている遺伝資源は実に 800 万点を超える (McCouch et al. 2013).これらの中には, 学術的に興味深 いもの，人類にとって有益な形質をもつものなどが多数 眠ったままとなっている。これらを掘り出し, 解明して いくことが, 次世代の研究者が担うべき重要な課題であ ると考光られる.

そこで, 本ワークショップではマニアックな植物を扱っ ている研究者 4 名を招聘し, 講演して頂いた。 それぞれ の研究対象は, 食虫植物フクロユキノシタ, 雌雄異株植 物ヒロ八ノマンテマ, イネ科雑草メリケンカルカヤ, そ してマメ科Vigna 属野生種群，といった珍しい植物ばか りであり，これらはモデル植物から想像もできないよう な特徵を備えている，各研究者の講演を聞き，議論を交 わすことで，今後の野生植物を用いた研究の拡大を推進 することを本ワークショップの目的とした．以下は話題 提供者が講演内容をまとめたものであり，本稿の読者が 研究に取り組む上で参考になることを期待したい. 
演題 1 フクロユキノシタのゲノムから探る食虫植物の 適応進化

福島健児 1,2 , 長谷部光泰 1,2 (1. 総研大 - 生命科学, 2. 基礎生物学研究所）

漸進的な形質進化が個々の変異の積み重ねで説明でき るのに対し,「複数の形質が組み合わさって機能する場合 はどのように進化するのか」といら問題は, 進化学上の 未解決課題として残されている（Barton et al. 2007）。食 虫植物の進化はその典型例であり, 特殊な葉形態や消化 機能といった複数の形質が揃らことではじめて捕虫能力 を発揮できる。我々は食虫植物を複合的な形質進化のモ デルケースと捉え，その進化過程の解明を目的として研 究に取り組んでいる.

\section{1.フクロユキノシタを用いた食虫性関連遺伝子の探索}

食虫植物はこれまでに拈よそ700 種が記載されて扮り， 粘り着け式や落とし穴式など種ごとに多様な罠を張り虫 を捕らえる。その中でも，我々はオーストラリアに分布 する落とし穴式食虫植物フクロユキノシタに着目した（図 1)。本種は虫を捕らえることが可能な捕虫葉と光合成に 適した普通葉の両方を作り出す能力を有する。作り分け の機構はこれまで不明であったが，我々は培湌条件の違 いのみによって葉の発生運命を制御できることを発見し た。これにより，個体内比較解析を起点とした食虫性関 連遺伝子の探索が可能となった。次に，捕虫能力を担う 遺伝子を網羅的に探索するにはゲノム配列情報が必要で ある。しかしながら，フクロユキノシタのゲノムサイズ は $2 \mathrm{Gbp}$ と大きく，全配列決定は容易ではなかった。そ こで, 新学術領域研究「複合適応形質進化の遺伝子基盤 解明」および Beijing Genomics Institute との共同研究を推 進し， Illumina および PacBio シーケンサーを組み合わせ ることでゲノムサイズの問題に対処した。そその結果，遺 伝子モデルの構築に十分な質のゲノム配列を得ることが できた。 さらに，フクロユキノシタに打けるウイルス誘 導性遺伝子抑制法の確立にも成功して扣り，トランスク リプトーム比較と遺伝子抑制スクリーニングを組み合わ せた遺伝子単離を進めている。

\section{2. 消化酵素の分子収斂}

食虫植物は被子植物における6つの目で独立に出現し ている（Albert et al. 1992）。我々は，独立に食虫植物化 した分類群間であってもその進化過程には何らかの共通 点があるのではないかと考光た。そこで，消化液内タン パク質のプロテインシーケンシングと捕虫葉のトランス クリプトームシーケンシングを組み合わせ，フクロユキ ノシタを含む 3 目 4 種の食虫植物から計 43 個の消化酵 素遺伝子を同定した。配列比較の結果，独立に食虫植物 化した分類群であるにも関わらず，これらの遺伝子は才 ルソログ関係にあることが分かった，当該遺伝子の非食 虫植物オルソログは病害抵抗性遺伝子であったことから

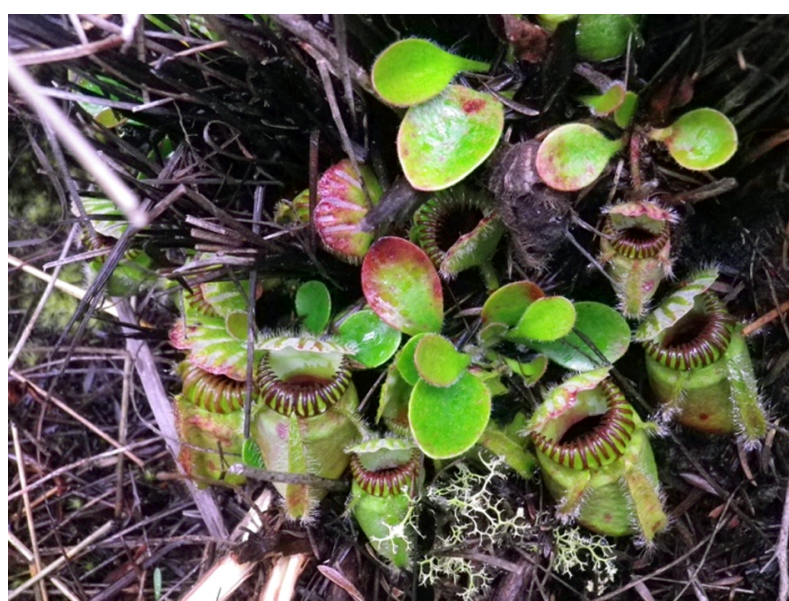

図 1. 春先に普通葉を作り始めるフクロユキノシタ（オースト ラリアアルバニーにて撮影).

(Okabe et al. 2005)，病原菌を溶かし殺す機能が前適応と なり，これが消化機能へと繰り返し転用されたと推定し た. 次に，アミノ酸置換レベルでの共通点を探索したと ころ，独立系統の消化酵素に拈いて，同一アミノ酸置換 が複数生じたことが明らかとなった。このことから，食 虫植物間で類似した選択圧が消化酵素の分子収斂を駆動 した可能性が示唆された。

近年，様々な生物のゲノム情報が利用可能となり，ゲ ノムスケールの解析から分子収斂のメカニズムを探るた めの基盤が整いつつある。本研究では消化酵素に着目し たが，ゲノムワイドな解析が可能になれば，分子収斂を 指標として複合形質進化の基盤を成す遺伝的変化を網羅 的に同定できるはずだと考光，研究を進めている.

演題 2 巨大 $Y$ 染色体との格闘 〜ヒロハノマンテマの 性決定遺伝子の探索〜

風間裕介 ${ }^{1}$, 石井公太郎 ${ }^{1}$, 池田時浩 ${ }^{1}$, 川元寛章 ${ }^{2}$, 河野

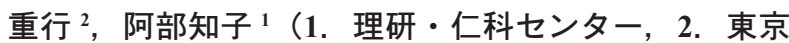
大・院・新領域・先端生命)

ナデシコ科の雌雄異株植物ヒロハノマンテマ（Silene latifolia）は，XY 型の性染色体を如（図 2).1923 年に $\mathrm{XY}$ 性染色体が発見されて以来，アメリカ，イギリス， フランス，チェコ，スイス，日本の研究グループにより ヒロ八ノマンテマを用いた性染色体の構造と進化や性分 化機構の解明に向けた研究が進められてきた。Y染色体 には3つの雄性決定機能領域があり，（1）雌芯発達抑制 機能領域 (GSF)，（2）雄芯伸長促進機能領域（SPF），(3) 葯成熟促進機能領域（MFF）と呼ばれる。私たちは，七 ロ八ノマンテマの雄（の゙）に理研リングサイクロトロン で発生する重イオンビームを照射し，（1）GSFを欠失し た両性花を 17 個体，（2）SPF を欠失した無性花を 10 個 体，（3）MFF を欠失した雄芯葯不全花を 6 個体単離し た。一方，イギリスの研究チームでは，1452 個の Y 染色 体座乗遺伝子を単離した。 これらの変異体と Y 染色体座 


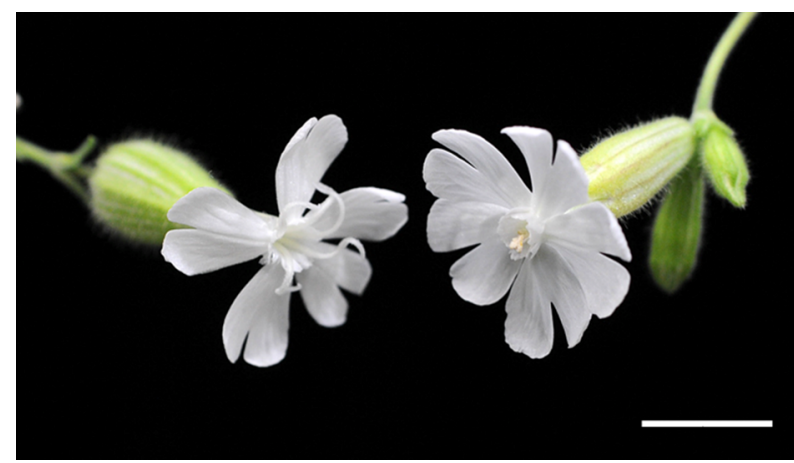

図 2. 雌雄異株植物ヒロ八ノマンテマの雌花 (左) と雄花 (右). bar $=1.0 \mathrm{~cm}$.

乗遺伝子群を用いて, 性決定遺伝子の単離を目指した研 究を開始した。組換光抑制領域が大部分を占める Y 染色 体では，組換え価による遺伝子のマッピングは行えない。 この問題を解決する方法として考案した「巡回セールス マン問題を応用した Y 染色体欠失マッピング」を中心 に, 本公演では, 植物性決定遺伝子の探索と性染色体の 構造解析について紹介した.

上記变異体と, 照射後変異表現型を示さなかった個体 計 96 個体について, 146 個の Y 染色体 STS マーカーを 用いて Y 染色体の欠失状況を調べた。「久失変異は局所 的に生じる」という仮定のもと, Y 染色体のマッピング を「各個体の欠失総数が最少となるマーカーの順列を求 める」といら巡回セールスマン問題に帰着した。順列の 組み合わせは（146-1）!/2 通りと膨大なため，まずマー カーをクラスタリングし, 各クラスターを仮想的なマー カーとして最適な順列を求め, 次に各クラスター内部の マーカーについて最適な順列を求めることで計算を効率 化した．どの個体にも欠失のない 10 個を除いた 136 マー カーをマップしたところ，Y 染色体は 2 つの領域に分け られた。 これら 2 領域の間に動原体があると考兄られる. 動原体から遠い順に GSF と SPF が同腕にマップされた が，MFFはマップできなかった。 マーカー数が不十分 か, MFF 遺伝子が複数存在することを示唆する. GSF， SPF 上のマーカーはそれ艺れ 4 個，5個であり，これら の近傍に性決定遺伝子が 1 つずつ存在すると考光られる. GSF と SPF の候補の抽出のため, レーザーマイクロダイ セクションと, 両性花変異体や無性花変異体を用いた発 現解析を行った。その結果, GSF の候補として4 遺伝 子, SPF の候補遺伝子として 32 遺伝子を得た。現在これ らの情報を統合して性決定遺伝子の探索を進めている.

最近, マメガキの Y 染色体に座乗する MFF 様の遺伝 子が報告され (Akagi et al. 2014), 植物性決定遺伝子の研 究はいよいよ盛んになってきている，今後は様々な植物 で雄性決定機能遺伝子が同定され，組換え抑制による性 染色体の獲得と進化汪関する研究が進められるであらう. 組換光抑制は，性決定遺伝子周辺だけでなく $S$ 遺伝子や アポミクシス遺伝子など様々な重要遺伝子の周辺に生じ
ており，本公演で紹介した重イオン欠失マッピングは， 様々な育種学上有用な遺伝子の同定にも適用できる技術 であると考えられる.

演題 3 イネ科野生植物メリケンカルカヤにおける $\mathrm{Al}$ ス トレス下でのエピジェネティックな遺伝子制御について 江崎文一（岡山大・資植研）

野生植物には幅広く環境ストレスに対して耐性を示す ものが多く, 耐性遺伝子や耐性機構を解析する上で大変 魅力的である。酸性条件下で植物の生育を阻害するアル ミニウム（Al）ストレスに対しても，高い耐性を示す野 生植物の存在が期待される. そこで野生植物群約 50 種か らの $\mathrm{Al}$ 耐性植物選抜を行い, イネ科野生植物のメリケン カルカヤ (Andropogon virginicus L.) を見出した. さらに その $\mathrm{Al}$ 耐性機構の解析を進め, 以下の結果を得た（図 3A）。1）根でストレス特異的に有機酸を合成し，根外一 も分泌することで毒性 $\mathrm{A} 1$ の無毒化と根への吸収を抑制す る.2）吸収した $\mathrm{Al}$ を根から地上部へ積極的に輸送し, 根での毒性濃度を低く抑える，3）地上部に移行した $\mathrm{Al}$ は葉の䊂状組織（トライコーム）等に集積され，さらに 一部はとこから排出される。）植物体内ではカタラーゼ や SOD 等の抗酸化酵素やアントシアニン等のポリフェ ノール類の生成が誘導され，Al ストレス下で 2 次的に発 生する酸化ストレスを軽減する，5）シグナル伝達物質で ある一酸化窒素（NO）を根で誘導し，抗酸化に作用する 上記の酵素類や物質類の体内生成を高める。この様に 1 つの植物で複数の耐性機構が見つかった報告例はない. またこれらの耐性機構の多くが誘導性であることから， 統括的な制御システムで起動される可能性が示唆される. そこでこれらの $\mathrm{Al}$ 耐性機構の解明を目的として,メリ ケンカルカヤ由来の cDNA ライブラリーを構築し, $\mathrm{Al}$ 耐 性遺伝子群の単離を酵母のスクリーニング系で行った。 得られた候補の 1 つは塩基配列の決定の結果, S-adenosyl methionin synthetase (SAMS) であった. その完全長 cDNA (AvSAMS1) をシロイヌナズナに導入したところ， $\mathrm{Al}$, $\mathrm{Cu}, \mathrm{Zn}$, diamide（酸化ストレスを引き起こす酸化剂）等 そも耐性であった，ところでSAMS は植物体内のメチル 化反応での主なメチル基供与体である SAM の合成に直 接関わることから DNA やヒストンのメチル化にも関与 すると思われた。 また上述のよらにメリケンカルカヤの 高い $\mathrm{Al}$ 耐性には, 複数の耐性機構のストレス特異的な誘 導が強く関連することが示唆され，ゲノム全体での発現 量の制御（エピジェネティックス）が $\mathrm{Al}$ ストレス下で起 こっている可能性が予想された. マイクロアレイでは, シロイヌナズナ AvSAMS1 発現株は非形質転換株（Col-0） に比べて $\mathrm{Al}$ 特異的に, より多くの遺伝子の発現量が増減 した（図 3B)。このことから AvSAMS1 が DNA やとスト ンのメチル化を介したエピジェネティック制御に関与す る可能性が示唆された。 そこで, アレイ解析で特徵的な 発現を示した遺伝子群（Col-0 株よりもAvSAMSI 発現株 
A

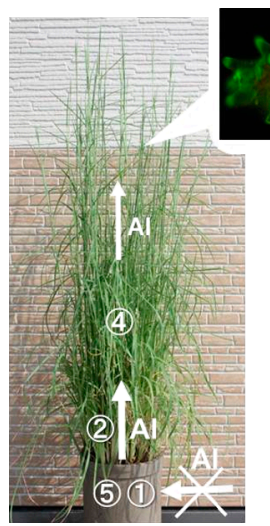

Al

(3)

(3) Accumulation and secretion of $\mathrm{Al}$ in leaf

(4) Induction of anti-peroxidation enzymes and poly-phenol by Al

(2) High Al transportation from root to shoot

\section{(5) Al-induced NO in root \\ (1) Suppression of Al uptake in root from soil}

B

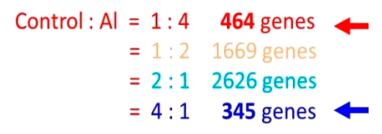

Col-0 line in Al stress

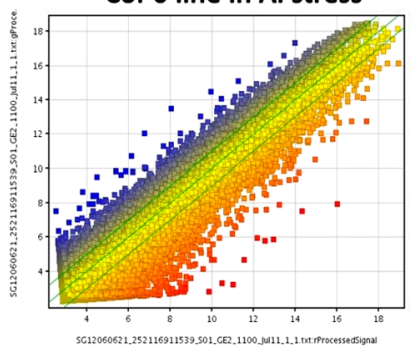

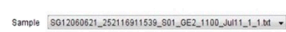

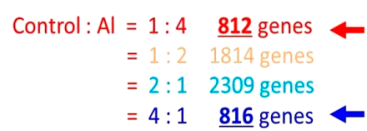

AvSAMS1 o/x TF line in Al stress

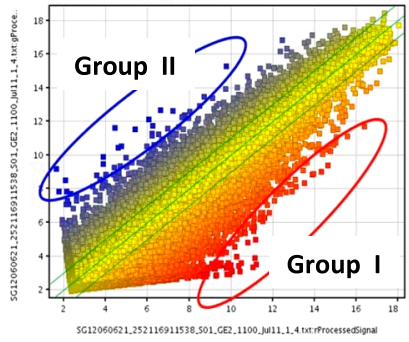

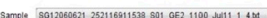

図 3.メリケンカルカヤの $\mathrm{Al}$ 耐性機構（A）とシロイヌナズナ AvSAMS1 発現株とコントロール株（Col-0）間での Al ストレス下の遺 伝子発現の比較（B)．マイクロアレイの結果を発現パターン毎に分類してゲノム上の遺伝子数を上部に示した. Group I と II は, Col-0 株よりも AvSAMS1 発現株でA1 ストレス時にその発現量が大きく誘導された遺伝子群, または抑制された遺伝子群である.

で $\mathrm{Al}$ ストレス時にその発現量が大きく誘導された遺伝子 群（図 3B；以下 Group I とする）または抑制された遺伝 子群（図 3B；Group II とする）について2つの検討を現 在進めている。 まず $\mathrm{Al}$ ストレス下での DNA メチル化の 状況を bisulfite 化反応後の塩基配列決定で検討したとこ ろ,（1）シロイヌナズナでは $\mathrm{Al}$ 処理により, Group I, II の両群に颃いて DNA のメチル化に変化が起こる遺伝子 が存在すること，（2）AvSAMSI 発現株と Col-0 株ではと のメチル化の状況に差異があることを見出した，一方， 遺伝子発現制御とヒストン H3 のメチル化との関係につ いても検討している。 こちらは DNA 以上飞複雑で, 既 に H3K4m3（ヒストン H3 の N 末から 4 番目のリジンの トリメチル化）または $\mathrm{H} 3 \mathrm{~K} 9 \mathrm{~m} 3 （ \mathrm{H} 3$ の $\mathrm{N}$ 末から 9 番目 のリジンのトリメチル化）とDNA との結合はその DNA 部位の発現誘導化または抑制化にそれぞれ，働くことが 知られている。 そこで前述の Group I と II から選んだ各 20 個について, 上記の 2 種類のメチル化ヒストンとの結 合状況をクロマチン免疫沈降（ChIP）法で検討した．そ の結果, Group I の中から $\mathrm{H} 3 \mathrm{~K} 4 \mathrm{~m} 3$ と結合量が $\mathrm{Al}$ 処理時 に, しかも AvSAMSI 発現株で, より大きく増加する遺伝 子群が得られた。一方 Group II の中からは H3K9m3 との 結合量が増える遺伝子群が得られた。 これらの結果はメ チル化ヒストンとの結合状況に合わせて遺伝子発現量が 制御される遺伝子群の存在を示唆している.

これまでに我々は耐性遺伝子候補の導入やそれらを統 括的に制御する転写調節因子遺伝子を導入して, 耐性化 を高めようとしてきた，今後，AVSAMS1 遺伝子の様なゲ ノム全体の発現量を制御する系の導入も, 上り有効な方 法として期待されるだろう。

\section{演題 4 Vigna 属植物の進化と多様性 友岡憲彦（農業生物資源研究所）}

\section{はじめに}

野生のVignaを探してアジア各地を旅しながら，考兄 ていたことがある。Vignaの野生種の中には作物になっ た（人間に選ばれた）ものとなれなかった（選ばれなかっ た）ものがある。何故だろら。なれなかったものの中に も, 地元の人々は結構食べているものがある. しかも, あるVignaの野生種を食べているインドの農民は, リョ クトウ（V.radiata）やケッルアズキ（V. mungo）より美 味であると言う。さらに，それを栽培している農民もい て, 次のように言う。こいつは病虫害に強いので, リョ クトウやケッルアズキを作る時には必要な農薬なんかや らなくても大丈夫. この野生種の種子は地元の種屋で売っ ていて，その值段はりョクトウょりも高かった，別の Vignaの野生種の利用について聞くと, 日照りなどの異 常気象で作物ができなかった時に, 救荒食として探して 食べると言う。異常気象の時でもこの野生種はちゃんと できているのだろらか，人間が食用として利用している Vigna の野生種の中には, 既存の作物では耐えられない ような劣悪な環境に適応して生えている種がある。であ れば，それを新たに栽培化して新作物にしたら，これか らの食糧生産の安定化に貢献できるのではないか.

\section{Vigna 属植物とは}

Vigna 属には約 100 種が記載されて初り，その中から 9 種が作物化された。一般に知られている作物としては, ササゲ (V. unguiculata)，リョクトウ，ケッルアズキ，ア ズキ (V. angularis) がある. あまり知られていないが, その涂かにちゃんと作物化された（大型化，種子休眠の 消失，裂萊性の消失がみられる）種としては，地下結実 性のバンバラマメ（V. subterranea），耐暑性に優孔たモス 
ビーン（V.aconitifolia），多収でアズキゾウムシ完全抵抗 性のッルアズキ (V. umbellata), Vigna 属唯一の 4 倍体種 クレオルビーン（V.reflexo-pilosa），イモを食用とするア カササゲ（V. vexillata）がある。 また，作物化されなかっ た種でも, 完熟種子, 未熟種子, 若葉, 花あるいはイモ が食用として利用されている種が 26 種ある.

\section{0 世紀最大の発明}

20 世紀が終わりを迎光る1999 年に, Nature 誌で Millennium essay といら特集が組まれ，その中に20世紀 で人類に最も大きな影響を与えた発明は何かといら小論 があった。 そこで取り上げられた 20 世紀最大の発明は, 飛行機でも, 核エネルギーでも, 宇宙船でも, テレビで も, コンピューターでもなく, ハーバーボッシュ法であっ た（Smil 1999）。これは，空気中の窒素を工業的に固定 する方法である。この発明により窒素（アンモニア）肥 料の大規模生産が可能となり, 農産物の生産量が増加し, 人口爆発の引き金となった。この発明がなかったら，現 在世界に暮らしている人々の半分は存在していない世 世 界の穀物生産は, 1960 年から 2000 年までの 40 年間に約 2.5 倍に増加したが (Green Revolution)，その穀物生産の 増加は, 工業的に生産された 8 倍の窒素肥料, 2 倍の灌 溉水， 7 倍の殺虫剤の投入によるものであった（Tilman et al. 2002). 窒素肥料の生産には大量の化石燃料が必要 であり，これに過度に依存する農業は持続的農業とはい えない。それだけでなく、これら資材の農地への過剩投 入は多くの環境污染問題をもたらした.

\section{Symbiotic Green Revolution}

一方，マメ科植物は八ーバーボッシュ法よりもはるか に高効率で化石燃料も必要としない空中窒素固定法をバ クテリアとの共生によって約 6500 万年前に発明した (Udvardi and Scheible 2005)。これは, Symbiotic Green Revolution と呼ばれ，現在農地に投入される窒素の半分 （約 5000 万トン）は，マメ科作物の共生窒素固定によっ て供給されている，今後の農業に捖いては，持続可能で 環境に負荷の少ない窒素固定能力をもつマメ科作物を作 付体系の中により多く組み入れて利用していくべきであ る.

\section{マージナルランドにおける作物生産}

先に述べた穀物生産の倍増は, 収量の増加によるもの であった。すすなわち, 主要穀物の収量は, 1960 年 $(1.2 \mathrm{t}$ ha）から 2000 年 (2.8 t/ha) の間に約 2.3 倍に増加した。 これは，農地として既に利用されていた土地の中のいわ ゆる ‘best quality farmland’ へ, 上述のように窒素, リ ン, 灌溉水，農薬を大量に投入し，それに耐えらる品種 を育成した結果である。そのため, 主要穀物の収量は既 に上限に達していると考光られており，今後大きな収量 増加は望めそらにない。従って 2050 年には 96 億に達す
ると予想されている人口増加に対応した食糧増産は, こ れまで農地として利用されていなかった条件の悪いマー ジナルランドに抢ける作物生産に頼らざるを得ない，ま た，現在農地として利用されている土地でも，その70\% はいわゆる 'problem soils (問題土壤) である。こうし た劣悪環境下での持続的作物生産にチャレンジしていく ためには，各種の問題土壤での栽培に適した新しい作物 が必要である.

\section{Neo-domestication}

野生植物の作物化の過程で起こった形態的変化は，農 耕の開始以降の比較的短期間（数千年から 1 万年）飞成 し遂げられた比較的少数の遺伝子の劣性突然変異（loss of function 型突然変異）によることが明らかになってき た。一方，問題土䁃を含む多様なストレス環境に対する 進化的適応は，一般に数十万年から数百万年という時間 をかけて獲得した複雑な遺伝子ネットワークによるもの である. 従って, 既存の作物に複雑な遺伝子ネットワー クを導入するよりも，既に環境ストレスに進化的に適応 を遂げた野生植物を，突然変異育種の手法や交配による 栽培化遺伝子の導入で新たに作物化する方がより効果的 なアプローチであろう（Tomooka et al. 2014）。これまで は，エリート作物の改良の時代であったが，いよいよ野 生種の出番がやってきた.

\section{Vigna 属植物の多様性}

Vigna 属植物の中には多様な環境に適応した種が進化 して扣り，これらは環境適応のメカニズムを明らかにす る興味深い材料であると同時に, Neo-domestication の候 補である (以下 Tomooka et al. 2014 の Fig. 2 参照). Vigna marina は熱帯の砂浜に生息する種で優孔た耐塩性を獲得 している。イモを食用にするV.vexillataの中には，酸性 土㙵に適応した系統があり, $\mathrm{pH} 3$ の酸性条件下で, $\mathrm{pH} 6$ の時に比べて約 30\%増の乾物生産を示すだけでなく, Al イオンを添加すると根量が増加する，V. exilis は，石灰岩 の山に適応した種で, 露出した石灰岩の上に直接生育す ることができるＶ. trilobataは，乾燥熱帯の砂質土㙥に 適応した種で, 長く伸びる直根で乾燥に耐える.V. luteola は，熱帯の河川脇等の湿地環境に適応した種である。 $V$. stipulacea は, 熱帯の重粘土土㙥に適応した種で，優れた 病虫害耐性をもっている。生物研圃場に执いて, アズキ 遺伝資源増殖围場では 2 週間に 1 度の殺虫剂散布をして も虫の被害が甚大であったのに対し，V. stipulacea の固場 は殺虫剤を全く散布しなくてもほとんど被害を受けな かった。

\section{ストレス環境下における窒素固定}

窒素を自己調達できるといらマメ科植物の能力は, 問 題土壌に打ける環境負荷の少ない持続的農業を考光る上 で，非常に重要な特徵である。 ある問題土壌に適応した 
マメ科植物を栽培する場合には，その環境に適応した根 粒菌を接種菌として利用すべきである。沖縄の砂浜に自 生しているV. marinaには, 一般にVigna 属植物に着生す るとされている Bradyrhizobium 属根粒菌ではなく, Rhizobium 属や Sinorhizobium 属に属する多様な未知の根 粒菌が着生していた。予想通り，これらの未同定根粒菌 は, Bradyrhizobium 属菌や既知の Sinorhizobium fredii USDA205 株と比較して, 極めて高い耐塩性 $(5 \% \mathrm{NaCl})$, 耐アルカリ性 $(\mathrm{pH} 11)$, 耐暑性 $\left(45^{\circ} \mathrm{C}\right)$ を示した。様々 なストレス環境に適応しているVigna 属植物に着生して いる根粒菌の研究は匡とんど行われて和らず，今後取り 組んでいくべき重要な課題である.

\section{おわりに}

乾燥に対するVigna 属植物 27 種の反応を調べて思っ た. Vigna 属で既に作物化されている種は, 祖先野生種 でも作物でも，水が潤沢な時には極めて旺盛な生育を見 せたが，乾燥がくると途端に破たんした，乾燥に適応し た野生種は，水が潤沢な時でも，あまり旺盛な生育を見 せない，その代り，乾燥がくると光合成活性を高め，根 の生産に資源を優先的に振り分けて, 生育を維持するこ とができた。いろんな野生種を栽培した経験から，環境 ストレスに適応した野生種は，人間が過保護な条件（十 分な水と肥料) を与えても，それに反応して旺盛に生長 するよらなことはなく，特に生育初期はゆっくりと生長 するょらに感じている，ひょっとすると，この間に環境 ストレスに対する何らかの準備をしているのかもしれな い. これからの農業に拈いては, 普遍性・単一性・経済 効率の追求から地域性・多様性・持続性の重視へ, 考光 万の転換が必要である。特に，ストレス環境下の農業で は，過保護な条件下に打ける収量性や経済効率に優れた エリート作物ではなく, 環境ストレスに適応した野生種 に由来する新作物が活躍するのではないだろらか.

\section{総 括}

重要作物やモデル植物をいわゆる植物界のエリートと するならば，野生植物の存在はその対極にあると言える. しかしその野生植物が魅力的に見えるのは，それぞれが ニッチの中に自分の居場所を見つけ，力強く生き延びて いるからではないだろらか。それは，喻えマニアックな 研究であっても自分の旗を振っている研究者の姿を想起 させる、「鶏口と為るも牛後と為る勿れ」とはよく言った ものだが，野生植物のように異彩を放つ研究者もまた， 魅力的なものであろらと思う.

当日は大変多くの方々にご参加頂いた．若手研究者や 学生に加えて著名なべテラン研究者にもご参加頂いたこ とは我々にとって大変喜ばしいことであった。今回は特
に普段の育種学会講演会ではまず触れる機会のないよら な植物を扱っている演者を中心に講演をして頂いた。 そ れぞれの植物が見せる特有の魅力や，マニアックな植物 であるがゆえに工夫された研究手法など，参加者にとっ ては参考や刺激になる内容であったと思いたい，

日本育種学会若手の会ではメーリングリストを作成し ており, 論文・求人などの情報交換および研究会の話題 提供者募集・開催予告などに利用している。本稿の読者 も是非, 定例の研究会和よびメーリングリストに参加し て我々と議論を交わして頂きたい.メーリングリストは 野菜茶業研究所の宮武宏治が管理しており, 参加希望の 方は以下のアドレスまでご連絡を頂きたい (miya0424@affrc.go.jp).

\section{謝 辞}

会場を提供してくださった大会運営委員会の先生方和 よび会場スタッフの方々には大変お世話になった。 また, 開催準備を手伝って頂いた日本育種学会若手の会の皆様 およびワークショップに参加して頂いた方々にも深く感 謝の意を申し上げる.

\section{引用文献}

Akagi, T., I.M. Henry, R. Tao and L. Comai (2014) A Y-chromosomeencoded small RNA acts as a sex determinant in persimmons. Science 346: 646-650.

Albert, V.A., S.E. Williams and M.W. Chase (1992) Carnivorous plants: phylogeny and structural evolution. Science 257: 14911495.

Barton, N.H., D.E.G. Briggs, J.A. Eisen, D. Goldstein and N.H. Patel (2007) Evolution. Cold Spring Harbor Laboratory Press, New York.

McCouch, S., G.J. Baute, J. Bradeen, P. Bramel, P.K. Bretting, E. Buckler, J.M. Burke, D. Charest, S. Cloutier, G. Cole et al. (2013) Agriculture: feeding the future. Nature 499: 23-24.

Okabe, T., I. Yoshimoto, M. Hitoshi, T. Ogawa and T. Ohyama (2005) An S-like ribonuclease gene is used to generate a trap-leaf enzyme in the carnivorous plant Drosera adelae. FEBS Lett. 579: 5729-5733.

Smil, V. (1999) Detonator of the population explosion. Nature 400: 415.

Tilman, D., K.G. Cassman, P.A. Matson, R. Naylor and S. Polasky (2002) Agricultural sustainability and intensive production practices. Nature 418: 671-677.

Tomooka, N., K. Naito, A. Kaga, H. Sakai, T. Isemura, E. OgisoTanaka, K. Iseki and Y. Takahashi (2014) Evolution, domestication and neo-domestication of the genus Vigna. Plant Genetic Resources: Characterization and Utilization 12: S168S171.

Udvardi, M.K. and W. Scheible (2005) GRAS genes and the symbiotic green revolution. Science 308: 1749-1750. 


\section{当日 演題}

ワイルドはセクシーだ！（育種学と農学のこれからを考える 28）

企画者: 高橋 有 ${ }^{1,2}$, 山内卓樹 2,3 , 内藤 健 ${ }^{1}$ (1. 農業生物資源研究所, 2. 日本学術振興会特別研究員 PD, 3. 名大 院生命農学)

1.フクロユキノシタのゲノムから探る食虫植物の適応進化

福島健児 1,2 , 長谷部光泰 1,2 (1. 総研大・生命科学, 2. 基礎生物学研究所)

2. 巨大 Y 染色体との格闘〜ヒロハノマンテマの性決定遺伝子の探索〜

風間裕介 ${ }^{1}$, 石井公太郎 ${ }^{1}$, 池田時浩 ${ }^{1}$, 川元寛章 ${ }^{2}$, 河野重行 ${ }^{2}$, 阿部知子 ${ }^{1}$ (1. 理研・仁科センタ一, 2 . 東京大・ 院・新領域・先端生命)

3. イネ科野生植物メリケンカルカヤに拈ける $\mathrm{Al}$ ストレス下でのエピジェネティックな遺伝子制御について 江崎文一（岡山大・資植研）

4. Vigna 属植物の進化と多様性

友岡憲彦（農業生物資源研究所） 